\title{
HUKUM KELUARGA DI MESIR
}

\author{
Nurinayah \\ Dosen Fakultas Syariah IAIN Palu \\ Email: inayahbahry@gmail.com
}

\begin{abstract}
The application of family law in Muslim-majority countries, especially the Middle East and its surroundings, has different practices, we do not find uniformity in family law practices in these countries. This is influenced by differences in government systems, cultures, situations and conditions of society of each country. Egypt is one of the predominantly Muslim countries which has established Islam as the state religion. Therefore, the principles of Islamic law are the main source of law in the making and formulation of laws, including family law. The practice of Islamic law in Egypt does not fully apply only to areas of family law in a limited scope including the distribution of inheritance and marriage. However, the application of family law in Egypt continues to undergo reforms and reforms. Family law reform took place in Egypt in 1920. This was marked by the promulgation of Law no. 25/1920 regarding family law and care (Law of Maintenance and Personal Status / Qanun al-Ahwal alSyakhsiyyah wa al-Siyanah). Family law reform in the 1970s was marked by the issuance of laws regarding the authority to the judiciary to force parties (husbands) to pay maintenance fees to wives, widows, children, or parents in 1976. the current era of family law in Egypt continues to experience development.
\end{abstract}

Keywords: Renewal, Family Law, Egypt

\begin{abstract}
Abstrak
Penerapan hukum keluarga di negara-negara yang berpenduduk mayoritas Muslim khususnya kawasan Timur Tengah dan sekitarnya memiliki praktik yang berbeda-beda, kita tidak menemukan keseragaman praktik hukum keluarga di negara-negara tersebut. Hal ini dipengaruhi oleh perbedaan sistem pemerintahan, kultur, situasi dan kondisi masyarakat setiap negara. Mesir merupakan salah satu negara yang berpenduduk mayoritas Muslim yang menetapkan Islam sebagai agama negara. Karena itu, prinsip-prinsip hukum Islam menjadi sumber hukum utama dalam pembuatan dan perumusan undang-undang termasuk hukum keluarga. Praktik hukum Islam di Mesir tidak berlaku secara utuh hanya bidang-bidang hukum keluarga dalam ruang lingkup yang terbatas meliputi pembagian warisan dan perkawinan. Namun, penerapan hukum keluarga di Mesir terus mengalami reformasi dan pembaruan. Pembaruan
\end{abstract}


hukum keluarga terjadi di Mesir pada tahun 1920. Ini ditandai dengan diundangkannya UU No. 25/1920 mengenai hukum keluarga dan penjagaan (Law of Maintenance and Personal Status/Qanun al-Ahwal alSyakhsiyyah wa al-Siyanah). Reformasi hukum keluarga pada tahun 1970an ditandai dengan dikeluarkannya aturan undang-undang mengenai kewenangan kepada lembaga peradilan memaksa pihak-pihak (suami) untuk membayar uang pemeliharaan kepada isteri-isteri, janda-janda, anak-anak, ataupun orang tua pada tahun 1976. Hingga era sekarang hukum keluarga di Mesir terus mengalami perkembangan.

Kata Kunci: Pembaruan, Hukum Keluarga, Mesir

\section{A. Pendahuluan}

Jika berbicara hukum Islam dan pelaksanaannya di beberapa kawasan Timur Tengah dewasa ini, khususnya Mesir, maka akan kita dapati fakta adanya keberagaman aturan hukum, praktik hukum, dan perundang-undangan yang dianut oleh setiap Negara yang menyatakan diri sebagai Negara Islam atau Negara yang mayoritas penduduknya muslim, hal ini disebabkan oleh perbedaan situasi, kondisi, dan kultur masyarakat Negara-negara tersebut, demikian halnya dengan sistem pemerintahan yang dianutnya.

Untuk melaksanakan hukum keluarga yang telah ditetapkan di Mesir, maka diadakan reorganisasi dan penyempurnaan peradilan agama dengan mengeluarkan peraturan perundang-undangan. Hukum keluarga yang dimaksudkan dalam pembahasan ini ialah hukum keluarga yang berlaku di Mesir yakni peraturan-peraturan yang oleh kalangan hukum diharapkan agar diterapkan dan dirujuk oleh pengadilan dalam menyelesaikan berbagai sengketa terkait keluarga di Mesir. Isi hukum keluarga yang diberlakukan pada masyarakat Mesir dalam kodifikasi, baik parsial maupun total; adalah merupakan pengembangan dari hukum keluarga Islam tradisional. 


\section{B. Pembahasan}

\section{a. Profil Negara Mesir}

Secara geografis, Mesir (Jumhuriyah Misr al-Arabiyah, Republik Arab Mesir) berada di pantai timur laut benua Afrika. Sisi utara berbatasan dengan laut tengah, timur dengan laut merah, selatan dengan Sudan, dan barat dengan Libya. Luas daerahnya sekitar 997.739 km². Mesir, Badui, dan Nubia adalah merupakan kelompok etnik terpentingnya. Ibu kotanya Kairo dengan bahasa resminya bahasa Arab. Sumber kehidupan Mesir adalah sungai Nil yang lembahnya merupakan dataran subur yang memanjang $\left(17.000 \mathrm{~km}^{2}\right)$ dengan kedua sisinya memiliki dinding karang setinggi $200-400 \mathrm{~m}^{1}$

Mesir telah mempunyai peradaban yang tinggi semenjak zaman kuno (4.000 tahun SM), sehingga dengan potensi geografis dan budayanya itu, ketika menjadi bagian dari wilayah Islam, Mesir dengan cepat menjadi daerah yang memiliki peranan penting dalam sejarah perkembangan Islam, baik di zaman pramodern maupun zaman modern. Peranan yang dilakukan Mesir dalam sejarah perkembangan Islam dapat dilihat dalam berbagai aspek, antara lain aspek politik dan perluasan daerah Islam, aspek ilmu pengetahuan, pendidikan dan kebudayaan dan aspek ekonomi perdagangan. ${ }^{2}$

Di tangan Amr ibn Ash, Islam masuk ke Mesir yang kala itu di bawah kepemimpinan Khalifah Umar ibn Khattab. Amr ibn Ash langsung menjadi amir di sana (632-660). Pemerintahan Mesir selanjutnya dipegang oleh Dinasti Umaiyah dan Abbasiyah secara berturut-turut, lalu Thulun (868-905), Ikhsyidiyah (935-969), Fathimiyah (909-1171), Ayyubiyah (1174-1250) dengan peristiwa perang salib sebagai tandanya, serta dinasti Mamluk (1250-1517), lalu menjadi bagian dari kekuasaan kerajaan Usmani. Kemudian secara bergantian, Mesir pernah dijadikan wilayah

${ }^{1}$ Ensiklopedi Islam, vol. 3, (Cet. III; Jakarta: PT Ichtiar Baru van Hoeve, 1994), 227

${ }^{2}$ Ibid., 227 
kekuasaan oleh Perancis, selanjutnya Inggris datang menggantikannya. Hingga pada tahun 1922, Mesir akhirnya merdeka. ${ }^{3}$

Agama memiliki peran besar di Mesir dewasa ini. Hampir $90 \%$ dari krang lebih 61 juta penduduk Mesir modern adalah muslim sunni. Ada beberapa penduduk beragama minoritas, yang terbesar adalah minoritas Kristen pribumi yang merupakan Gereja Kopti. Pada 1990, perkiraan jumlah penduduk Kopti yaitu antara 3 sampai 7 juta, sedangkan pemeluk Kristen lainnya mencakup kira-kira 350 ribu pengikut Gereja Ortodoks Yunani, 175 ribu Katolik Ritus Latin dan Timur, serta 200 ribu Protestan. Selain itu, diperkirakan pada 1990 sekitar 1 ribu orang Yahudi masih mendiami Mesir. Populasi Yahudi ini memberi gambaran sebuah fragmen komunitas yang berjumlah 80 ribu orang Yahudi yang hidup sebelum 1948 di Mesir. Ciri budaya Mesir tradisional adalah toleransi keagamaan yang tinggi, dimana kebebasan beragama dijamin oleh Konstitusi Mesir 1971 meskipun ketegangan sekitar agama sejak 1970-an meningkat tajam. ${ }^{4}$

Mesir secara historis memosisikan agama sebagai pusat segala sesuatu. Pada saat kekuasaan imperium Muslim awal lemah dan dinastidinasti lokal bermunculan di Mesir, pemimpin agama tetap berperan penting sebagai kekuatan sosial dan spiritual. Berdiri tegaknya Al-Azhar sebagai masjid dan universitas pada 970, telah menjamin Kairo sebagai tempat yang kondusif dalam cakrawala intelektual dan spiritual Islam. Abad ke 18, di Kairo lahirlah para ulama yang jumlahnya sekitar 4 ribu dari sekitar 50 ribu populasi laki-laki dewasa. Dari pusat mereka di Al-Azhar basis pengorganisasian jaringan pendidikan keagamaan secara nasionalulama Mesir menjaga budaya Islam yang menghasilkan mata rantai sosial dan moral yang kokoh antara Kairo dan berbagai provinsi yang ada. ${ }^{5}$

\footnotetext{
${ }^{3}$ Ibid,. 227

4 Ensiklopedi Oxford Dunia Islam Modern (terj. The axford Encyclopedia of The Modern Islamic World), vol. 4, (Cet. I; Bandung: Mizan, 2001), 49

5 Ibid., 51
} 


\section{b. Konstitusi, Sistem Peradilan Modern dan Mazhab Negara}

Republic Arab Mesir sebagaimana dinyatakan oleh Konstitusi 1980 adalah Negara demokrasi dan sosialis. Kedaulatan terletak di tangan rakyat dan rakyat merupakan sumber kekuasaan Negara. Semua warga Negara mendapatkan status persamaan di depan hukum. Islam dinyatakan sebagai agama Negara dengan sumber hukum utamanya berupa prinsip-prinsip hukum Islam dalam membuatan dan merumuskan undang-undang. Namun dalam praktiknya, hukum Islam secara utuh hanya berlaku dalam bidang-bidang perkawinan dan wakaf, pembagian warisan, sedangkan bidang-bidang perdata lainnya demikian juga pidana, hukum Islam tidaklah sebagai rujukan utama. la hanya menjadi salah satu sumber hukum Republik Arab Mesir. ${ }^{6}$

Adapun system peradilan yang berlaku di Mesir secara historis terbagi ke dalam dua fase. Pertama, fase pembaruan qadha. Fase ini menghasilkan lembaga-lembaga hukum yang menggarap beberapa kasus hukum, yaitu: (1) Mahkamah Mukhalitah (campuran) yaitu untuk orangorang asing yang memiliki hak istimewa menurut peradilan Mesir (2) Mahkamah Ahliyah yaitu untuk Mesir dan asing yang tidak mempunyai hak istimewa (3) Mahkamah Syar'iyah, menyangkut ahwal syakhsiyah hanya sebatas berlaku pada orang Mesir yang beragama Islam, sedangkan bagi non-muslim diambil alih oleh majelis Milly. Kedua, fase penghapusan hak-hak istimewa. Adapun yang menjadi sumber qanun dan kedudukan syariat Islam di Mesir sebagaimana telah ditetapkan pada 1948 adalah: (1) Undang-undang al-Mukhalitah dan al-ahli yang sebenarnya berasal dari undang-undang Perancis. (2) Undang-undang perdata modern yang juga diambil dari Perancis. (3) Hukum Mesir sebagai hukum yang dibutuhkan negara (4) Syariat Islam sebagai sebuah sumber resmi. $^{7}$

\footnotetext{
${ }^{6}$ Alaiddin Koto et. al, Sejarah Peradilan Islam, (Cet. I; Jakarta: PT Rajagrafindo Persada, 2011), 167
} ${ }^{7}$ Ibid,. 174 
Sedang pada persoalan mazhab yang diberlakukan, penduduk Mesir di awal sejarahnya merupakan penganut mazhab Syafi'i, kemudian ketika masuk dalam imperium Ottoman, Mesir menganut mazhab Hanafi. Meskipun begitu, Mesir adalah salah satu contoh Negara berpenduduk muslim terbesar yang di satu sisi menyuruh masyarakat muslimnya untuk bermazhab Hanafi, namun di saat yang sama mereka juga diperkenankan untuk memilih salah satu dari empat mazhab fikih yang secara umum dianut oleh mayoritas muslim di seluruh penjuru dunia. ${ }^{8}$

\section{c. Reformasi Hukum Keluarga Mesir}

Pada pertengahan dasawarsa kedua abad ke duapuluh, reformasi hukum keluarga baru terjadi tepatnya tahun 1915. Reformasi hukum keluarga ini dimulai dari Turki. Setelah Turki Usmani, pada tahun 1920 Mesir melakukan kodifikasi dan pembaruan hukum keluarga. Hal ni ditandai dengan dibuat dan diberlakukannya UU No. 25/1920 mengenai hukum keluarga dan penjagaan (Law of Maintenance and Personal Status/Qanun al-Ahwal al-Syakhsiyyah wa al-Siyanah). Reformasi hukum di Mesir terus dilakukan secara berkelanjutan hingga awal tahun 1950an. Lembaga hukum di Mesir secara bertahap mengadakan reformasi hukum yang memiliki pengaruh penting terhadap hukum keluarga (perkawinan dan waris). UU No. 25 Tahun 1920 ini kemudian diikuti oleh undangundang lainnya seperti UU No. 56/1923 mengenai batasan usia untuk melangsungkan perkawinan, UU No. 25/1929 mengenai aturan pertengkaran dan perceraian di dalam rumah tangga, lalu disusul oleh kitab undang-undang sipil/perdata (civil code) tahun 1931, UU No. 77/1943 berkenaan dengan hukum waris, dan UU No. 71/1946 dalam hukum wasiat. Setelah itu, dalam kurun waktu 1960an hingga 1970an, berbagai peristiwa politik juga ikut menjadi penentu dilakukannya reformasi hukum keluarga. Pada tahun 1970an, reformasi hukum keluarga

${ }^{8}$ Muhammad Amin Suma, Hukum Keluarga Islam di Dunia Islam, (Cet. I; Jakarta: PT Rajagrafindo Persada, 2004), 183 
ditandai dengan aturan undang-undang yang dikeluarkan mengenai pemberian kewenangan terhadap lembaga peradilan untuk memaksa pihak-pihak (suami) membayar uang pemeliharaan kepada isteri-isteri, janda-janda, anak-anak, ataupun orang tua. Pada tahun 1976, secara sepihak Presiden Anwar Sadat mengeluarkan dekrit darurat yang diundangkan menjadi UU no 44/1979, setelah gagal memperoleh persetujuan untuk mengeluarkan undang-undang dalam hukum keluarga. Undang-undang ini dikenal dengan nama undang-undang Jihan (Jehan's Law atau Jiji's Law), karena Jehan Sadat atau Jiji Sadat sebagai Isteri Anwar Sadat yang telah mengusulkannya. Undang-undang ini banyak melakukan revisi terhadap undang undang hukum keluarga mesir yang dihasilkan pada tahun 1920 dan 1929, utamanya mengenai peranan dan hak perempuan di dalam keluarga. ${ }^{9}$

Namun pada bulan Mei 1985, UU no 44/1979 ini digugat dengan adanya pengajuan judicial review ke Mahkamah Tinggi Konstitusi (High Constitutional Court). Pengajuan judicial review tersebut untuk menilai status undang-undang Jehan ini. Hasilnya, Mahkamah konsitiusi Mesir menerangkan bahwa undang-undang tersebut bertentangan (ultra vires) dengan Konstitusi Mesir. Mahkamah menolak status dekrit darurat undang-undang ini dengan alasan bahwa dekrit darurat yang telah dikeluarkan oleh Presiden Anwar Sadat untuk memberlakukan UU no 44 tahun 1979 sesungguhnya dikeluarkan tidak dalam keadaan darurat. Oleh karenanya dekrit tersebut mesti dianggap tidak valid. ${ }^{10}$

Setelah pembatalan undang-undang Jehan tersebut setelah beberapa bulan, pemerintah Mesir mengundangkan UU no. 100/1985, sebuah amandemen hukum untuk melakukan revisi hukum keluarga tahun 1920 dan 1929. Sejumlah perubahan yang telah diundangkan sebelumnya dalam UU tahun 1979, diundangkan ulang dalam undang-undang tahun

\footnotetext{
${ }^{9}$ Ahmad Bunyan Wahib, Reformasi Hukum Keluarga di Dunia Muslim, ljtihad: Jurnal Wacana Hukum Islam dan Kemanusiaan vol. 14 no. I, Juni 2014, 8

${ }^{10}$ Ibid., 8
} 
1985, serta ditambahkan dengan beberapa aturan baru. Hingga pada tahun 2005, Mesir mengeluarkan UU no 4/2005 yang isinya mengamandemen Dekrit Hukum No 25 Tahun 1920 (yang melakukan perubahan terhadap usia perwalian). ${ }^{11}$

\section{d. Analisis Perubahan Hukum}

Jika Turki melakukan pembaharuan hukum keluarga dengan mengadopsi hukum Code Civil Switzerland, maka Mesir memperbaharuinya dengan melakukan reformasi hukum pada hukumhukum fikih yang telah berlaku. Mesir adalah Negara yang pertama di Arab dan kedua setelah Turki yang mengadakan pembaharuan hukum keluarga. Pembaharuan ini sebagai respon terhadap perkembangan zaman dan keberanjakan dari fikih konvensional menuju pada konfigurasi hukum keluarga modern. Terutama dalam hal penyetaraan dan pengangkatan status wanita dalam perkawinan yang dipandang menjadi objek marjinalisasi.

Usaha pembaharuan Hukum Kelurga Mesir juga disokong oleh adanya tuntutan Gerakan Wanita di Mesir. Misalnya tuntutan dari The Egyptian Feminist Union yang diprakarsai pendiriannya pada tahun 1923 oleh Huda Sya'rawi. Kelompok ini mengusulkan sebanyak 32 butir tuntutan kepada Parlemen dan Pemerintah Mesir. Di antara tuntutan itu adalah: 1. Pendidikan kepada wanita, 2. Pembaharuan hukum keluarga, 3. Batas minimal perkawinan, 4. Pembatasan poligami, 5. Pembatasan hak cerai laki-laki. ${ }^{12}$

Meskipun ide-ide dari Muhammad Abduh, Qasim Amin, Safwat dan pemikir Mesir lainnya tentang teori pembaharuan hukum keluarga di Mesir benar-benar ditentang, namun pada kenyataannya ide-ide mereka telah banyak memginspirasi usaha pembaharuan tersebut. Tambahan pula,

\footnotetext{
11 Ibid., 9

12 Ulya Hikmah Sitorus Pane dan Muhammad Rozali, Analisis Fatwa Ali Jum'ah (Mufti Agung Mesir) Tentang Nikah Urfi Dalam Kitab "Al-Kalim Al-Thayyib" Fatawa Ashriyyah, Jurnal Al-Mizan vol. 12 no. 1, Juni 2016, 51
} 
bahwa Malik Hifni Nasif mengusulkan sepuluh butir pembaharuan hukum yang berkaitan dengan wanita, yang diberikan kepada Badan Legislatif Mesir tahun 1911. Empat diantaranya adalah pendidikan wanita, poligami, umur nikah, dan masalah jilbab. ${ }^{13}$

Reformasi hukum berkaitan erat dengan sejauh mana negara/pemerintah mengatur rakyat atau masyarakat secara efektif dan efisien. Ada banyak factor yang mempengaruhi perubahan itu, diantaranya disebabkan oleh alasan sosial, hukum, dan politik. Negaranegara muslim telah melaksanakan pembaharuan-pembaharuan hukum dengan alasan sosiologis, yaitu masyarakat membutuhkan adanya perubahan. Hukum yang baik semestinya dapat menjawab permasalahan yang ada dalam masyarakat yang selalu menanggung perkembangan dan kemajuan.

Sedangkan dari segi pemerintahan, alasan pembaharuan itu adalah efisiensi birokrasi hukum dalam tata negara bangsa. Tuntutan ini telah mendesak negara-negara muslim untuk melakukan modifikasi aturan hukum materiil dan melengkapi prosedur administrasi peradilan agama modern dengan melahirkan hukum acara Islam. Demi hukum, dibutuhkan adanya aturan hukum (legislasi hukum) yang sesuai dengan sistem hukum modern. Kepentingan ini bukan hanya berimplikasi kepada prosedur dan administrasi hukum, tetapi juga kepada substansi hukum. Contohnya adalah bukti tertulis untuk kasus hukum tertentu, seperti pembuktian suatu perkawinan dan perceraian dengan akta (peraturan tahun 1931 bahwa mesti ada bukti resmi atau akta dari pemerintah (official certificate). Kesaksian lisan tidak memadai untuk kasus hukum yang memerlukan bukti yang terperinci.

${ }^{13}$ Khoiruddin Nasution, Status Wanita di Asia Tenggara: Studi terhadap Perundang-undangan Perkawinan Muslim Kontemporer di Indonesia dan Malaysia dalam Ulya Hikmah Sitorus Pane dan Muhammad Rozali, Analisis Fatwa Ali Jum'ah (Mufti Agung Mesir) Tentang Nikah Urfi Dalam Kitab "Al-Kalim Al-Tayyib" Fatawa Ashriyyah, 51 
Adapun dari sisi politik, apa yang dialami oleh dengan UndangUndang Jehan (Jehan's Law) tahun 1979 di Mesir dapat menjadi contoh yang sangat baik. Undang-undang Jehan ini dikeluarkan ketika Pemerintahan yang saat itu dipimpin oleh Anwar Sadat sangat kuat. Para pengamat menyebutkan bahwa Undang-Undang lahir ketika parlemen tidak ada pilihan lain untuk menyepakati draft yang diajukan oleh pemerintah. Empat tahun setelah Anwar Sadat terbunuh, yakni pada tahun 1985 Mahkamah Tinggi Konstitusi Mesir membatalkan undangundang Jehan karena dinilai tidak konstitusional. Undang-undang Jehan direvisi dengan Undang-undang No. 100 tahun 1985. Yang paling penting dari revisi tersebut adalah revisi hak cerai secara otomatis bagi isteri yang dipoligami. Hak otomatis isteri untuk bercerai diubah dengan hak bercerai setelah pengadilan mengeluarkan keputusan. Isi amandemen tersebut merupakan buah kompromi dari kalangan Muslim konservatif dan kelompok liberal. ${ }^{14}$ Arah kebijakan negara dalam bidang sosial politik memberikan pengaruh yang sangat penting dalam proses reformasi hukum di sejumlah negara Islam, Teradinya pembunuhan terhadap Anwar Sadat di Mesir; ketidakpuasan masyarakat akan hasil reformasi hukum, juga pengadopsian aturan baru yang dinilai terlalu radikal dan tidak sesuai dengan aturan hukum syariah. Oleh sebab itu, saat pergantian kekuasaan terjadi, perubahan aturan hukum keluarga pun dilakuan. ${ }^{15}$

\section{e. Penerapan Hukum Keluarga}

Berikut ini beberapa hal yang perlu diketengahkan dalam hukum keluarga Negara Mesir: ${ }^{16}$

1. Batas minimum usia perkawinan ${ }^{17}$

${ }^{14}$ Wahib, Reformasi Hukum, 17

15 J.N.D. Anderson, Change in the Islamic Law of Personal Status in Iraq, The International and Comparative Law Quarterly, Vol. 12, No. 3 (Juli, 1963): 1026-1031, dalam Ahmad Bunyan Wahib, Reformasi Hukum Keluarga di Dunia Muslim, 17

${ }^{16}$ Kurniati, "Hukum Keluarga di Mesir", Al-Daulah 3, no. 1 (Juni 2014), Lihat Muhammad Siraj "Hukum Keluarga di Mesir dan Pakistan" dalam Johannes Den Heijer dan Syamsul Anwar, [ed], Islam, Negara dan Hukum (Jakarta: INIS, 1993), 99-114,

${ }^{17}$ Ibid., 27 
Alquran dan hadis sebagai sumber primer syariat Islam memang tidak pernah menetapkan usia minimum untuk diberlangsungkannya perkawinan, namun demi terwujudnya kerukunan yang abadi dalam sebuah rumah tangga, maka pakar hukum Islam Mesir telah menetapkan undang-undang tentang usia minimum perkawinan dalam Pasal 99 ayat 5 Tahun 1931. Bahwa usia pria minimal 18 tahun dan wanita minimal 16 tahun.

Dalam Pasal 99 ayat 5 undang-undang susunan Pengadilan Agama Tahun 1931, menyatakan: "Tidak akan didengar gugatan perkara keluarga apabila usia isteri kurang dari 16 tahun atau usia suami kurang dari 18 tahun." Hal tersebut bertujuan agar keharmonisan rumah tangga tetap terjaga.

\section{Pencatatan pernikahan ${ }^{18}$}

Dalam perkawinan, pencatatan nikah adalah masalah yang sangat pentin, melihat betapa banyak masalah yang timbul akibat tidak dicatatnya secara resmmi sebuah perkawinan. Di antaranya, masalah asal usul anak, kewarisan dan nafkah. Masalah-masalah ini pulalah yang menyebabkan negara Mesir melakukan usaha pencatatan ini. Terbitlah ordonansi tahun 1880 tentang pegawai-pegawai pencatat nikah, pengangkatannya serta tata cara pelaksanaannya. Lalu diikuti oleh ordonansi tahun 1897 dalam Pasal 31 yang menyebutkan bahwa pengadilan tidak akan melayani gugatan perkara nikah atau pengakuan adanya hubungan perkawinan setelah salah satu pihak meninggal, apabila tidak adanya bukti perkawinan melalui surat nikah yang sah dari pemerintah. Demikian halnya ordonansi tahun 1921 yang mengandung ketentuan bahwa surat nikah haruslah bersifat resmi yang mana dibuat oleh pegawai yang mempunyai wewenang.

${ }^{18}$ Ibid., 27 
Lahirnya penertiban administrasi modern di Mesir telah memberikan kemudahan dalam hal pencatatan akad. Dari sini jelas bahwa pihak yang membuat UU di Mesir mengambil prinsip "tidak mendengarkan sesuatu gugatan" dalam kasus-kasus perkawinan dan akibat-akibat hukumnya, jika perkawinan tersebut tidak dapat dibuktikan lewat suatu dokumen resmi yang diterbitkan oleh pejabat berwenang, seperti hakim dan pegawai pencatat nikah untuk pernikahan di dalam negeri, atau konsul (untuk pernikahan di luar negeri).

\section{Perceraian di depan pengadilan ${ }^{19}$}

Mesir tidak memberlakukan mazhab Hanafi pada masalah jatuhnya perceraian di depan pengadilan, namun Mesir memberlakukan mazhab Maliki. Hal itu ditandai dengan adanya undang-undang Tahun 1920 dan UU tahun 1929; isteri boleh meminta pemutusan perkawinan. Dua Undang-undang ini mengakomodasi hak wanita untuk meminta cerai karena suami tidak memberikan nafkah, suami menghilang selama 1 tahun, atau dipenjara selama 3 tahun dengan berkekuatan hukum tetap dan tidak bisa lagi melayani nafkah batin. Dalam hal ini, Mesir sengaja mengambil mazhab Maliki agar kepentingan sosial kemasyarakatan dapat teratasi dengan baik.

4. Poligami ${ }^{20}$

Adapun masalah poligami yang terdapat dalam QS. An-Nisa menyatakan bahwa syarat kebolehan poligami bisa berlaku adil, kalau tidak bisa, poligami haram, karena menimbulkan kesakitan. Maka isteri terdahulu diberikan hak minta pemutusan perkawinan kepada hakim sesuai dengan mazhab Maliki.

\footnotetext{
${ }^{19}$ Ibid., 27

${ }^{20}$ Ibid., 28
} 
Setelah beberapa waktu sesudah dibukanya perdebatan mengenai problematika poligami, pemikiran fikih di Mesir sampai pada suatu ketegasan di antaranya bahwa: wanita yang suaminya menikah lagi, maka penyelesaian hukum yang dibenarkan baginya adalah memberikan kepadanya hak untuk meminta pemutusan hubungan perkawinan dengan syarat bahwa sang wanita dapat memberikan bukti adanya kerugian yang dialaminya, seperti karena tidak menerima nafkah dari suami, diperlakuan secara kejam, tidak ditiduri atau kerugian lainnya semacam itu.

Jadi dalam Undang-undang Tahun 1929; isteri memiliki hak minta cerai jika perkawinan kedua sang suami dengan wanita lain menyebabkan baginya penderitaan dan UU tahun 1979; perkawinan lebih dari sekali hanya dibenarkan jika masing-masing isteri dan calon isteri telah diberi tahu tentang perkawinan yang lain dan mereka menyetujuinya, jika suami tidak melakukan lakukan hal demikian, maka dianggap perkawinan tersebut membuat isteri menderita dan karena itu berhak minta pemutusan perkawinan.

5. Putusnya perkawinan ${ }^{21}$

a. Pemutusan perkawinan tidak berlaku (tidak sah) pada seorang suami yang mabuk dan mengucapkan ucapan perceraian, berada di bawah paksaan, atau melakukan perceraian bersyarat. Perceraian baru dianggap sah jika suami bersungguh-sungguh bermaksud untuk memutuskan perkawinan.

b. Ucapan talak tiga sekaligus dari suami hanya berlaku satu talak.

c. Dalam jangka waktu tiga puluh hari sejak menjatuhkan talak, perceraian harus didaftarkan oleh suami yang telah menceraikan isterinya.

6. Ketentuan kewarisan

\footnotetext{
21 Hukum Keluarga Islam di Negara Mesir; Sebuah Resume, http://ciani-srihidayati.blogspot.co.id/2012/03/hukum-keluarga-islam-di-negara-mesir., (diakses pada hari Kamis, 3 Agustus 2020)
} 
Kewarisan dalam Undang-undang no. 77 tahun 1943, sebagian besar diambil dari mazhab Hanafi dan dalam beberapa kasus terdapat hukum yang berbeda dari mazhab tersebut. Berikut ketentuan hukum waris yang diberlakukan di Mesir:

a. Sesuai pendapat mazhab Hanafi bahwa sebelum hutang dibayarkan, maka biaya pemakaman mesti diutamakan untuk dikeluarkan.

b. Seorang ahli waris yang membunuh pewaris akan terhalang dari menerima warisan. Hal ini sesuai ketentuan hukum syariah. Sedangkan tentang jenis pembunuhan sengaja atau tidak sengaja yang dapat menghalangi diterimanya warisan terdapat perbedaan pendapat. Mazhab Hanafi menetapkan bahwa semua jenis pembunuhan dapat menghalangi ahli waris mendapatkan hak warisan. Sedangkan mazhab Maliki menetapkan hanya ahli waris yang sengaja membunuh saja yang dapat menghalangi dari mewarisi. Undang-undang (1943) Mesir mengadopsi pendapat mazhab Imam Malik tersebut. Pasal 5 menyatakan bahwa "salah satu hambatan ahli waris menerima warisan adalah ahli waris yang sengaja telah menyebabkan kematian pewaris, baik oleh dirinya sendiri, atau membantu membunuh, atau sebagai saksi yang kesaksiannya tersebut pewaris dieksekusi, sedangkan ahli waris dalam keadaan waras dan telah berusia 15 tahun.

\section{f. Indonesia dan Mesir dalam Hukum Keluarga ${ }^{22}$}

Dari sejumlah besar negara yang telah mempunyai undang-undang hukum keluarga Islam khususnya undang-undang perkawinan Islam, Republik Arab Mesir adalah yang paling memiliki sisi kemiripan dalam kondisi hukum dan system peradilannya dengan Indonesia. Rifyal Ka'bah menyimpulkan bahwa memang ada beberapa kemiripan antara Indonesia dan Mesir dalam sejarah hukum dan peradilannya:

${ }^{22}$ Muhammad Amin, Hukum Keluarga, 185. Lihat Rifyal Ka'bah, "Beberapa Permasalahan Dalam alAhwal asy-Syakhsiyah (Hukum Keluarga) Mesir”, Makalah, 19 September 2002 (Jakarta: Departemen Agama $\mathrm{RI}), 1$ 
Pertama, dalam bidang peradlan, Pengadilan Agama atau Mahkamah Syar'iyah adalah lembaga peradilan yang dominan di kedua negara tersebut sebelum penjajah Barat datang.

Kedua, dualisme pendidikan hukum dan peradilan yang samasama dirasakan oleh kedua negara. Di satu pihak terdapat pendidikan syariah untuk hukum Islam yang bermuara ke Pengadilan Agama, sedang di satu sisi terdapat pendidikan hukum untuk hukum warisan kolonial yang bermuara ke Pengadilan Umum.

Ketiga, dasar tradisi civil law kedua negara sama, di mana asal-usul hukum materiil dan hukum acaranya berasal dari Negara Perancis.

Keempat, kedua negara berupaya untuk menyatukan kedua system hukum dan peradilan dalam kerangka hukum nasional masing-masing.

\section{Penutup}

Dari uraian tersebut dapat disimpulkan beberapa hal berikut terkait hukum keluarga Islam di Mesir, yaitu:

1. Islam sebagai agama negara menjadikan sumber hukum utama dalam pembuatan dan perumusan undang-undang di negara Mesir adalah prinsip-prinsip hukum Islam. Sedang mazhab yang dianut oleh mayoritas penduduknya adalah mazhab Hanafi.

2. Hukum privat Islam di Mesir sudah menjadi satu dengan hukum privat umum. Demikian halnya dengan Peradilan Agama (Mahkamah Syar'iyyah) yang sudah menjadi satu dengan Peradilan Umum.

3. Isi hukum keluarga yang diberlakukan kepada masyarakat Mesir dalam kodifikasi, baik parsial maupun total; adalah merupakan bentuk pengembangan dari hukum keluarga Islam tradisional.

4. Sebagai respon terhadap zaman yang terus berkembang, dilakukanlah pembaharuan-pembaharuan dalam hukum keluarga di Mesir dan dimulailah perpindahan dari fikih konvensional kepada konfigurasi hukum keluarga modern. Hal demikian terjadi sebagai upaya penyetaraan dan pengangkatan status wanita. 
5. Dalam aspek prosedur perkawinan, Mesir memberikan perhatian pada masalah persyaratan perkawinan, pencatatan dan tatacara perkawinan. Adapun dalam perceraian, Mesir memberikan persyaratan yang cukup ketat. Sedang pada aspek poligami, mesir memperbolehkan dengan syarat tertentu.

\section{Daftar Pustaka}

Ensiklopedi Islam, vol. 3, Cet. III; Jakarta: PT Ichtiar Baru van Hoeve, 1994.

Ensiklopedi Oxford Dunia Islam Modern (terj. The axford Encyclopedia of The Modern Islamic World), vol. 4, (Cet. I; Bandung: Mizan, 2001)

Koto, Alaiddin et. al, Sejarah Peradilan Islam, Cet. I; Jakarta: PT Rajagrafindo Persada, 2011.

Kurniati, "Hukum Keluarga di Mesir", Al-Daulah 3, no. 1, Juni 2014.

Suma, Muhammad Amin, Hukum Keluarga Islam di Dunia Islam, (Cet. I; Jakarta: PT Rajagrafindo Persada, 2004.

Hukum Keluarga Islam di Negara Mesir; Sebuah Resume, http://www.ciani-sri-hidayati.blogspot.co.id/2012/03/hukumkeluarga-islam-di-negara-mesir.,

Pane, Ulya Hikmah Sitorus dan Muhammad Rozali, Analisis Fatwa Ali Jum'ah (Mufti Agung Mesir) Tentang Nikah Urfi Dalam Kitab "AlKalim Al-Thayyib" Fatawa Ashriyyah, Jurnal Al-Mizan vol. 12 no. 1, Juni 2016.

Wahib, Ahmad Bunyan, Reformasi Hukum Keluarga di Dunia Muslim, ljtihad: Jurnal Wacana Hukum Islam dan Kemanusiaan vol. 14 no. I, Juni 2014. 